UDC 1(091)

LBC 87.3

\title{
PECULIARITY OF THE CONCEPT OF LIBERATION IN VIETNAMESE BUDDHISM ${ }^{1}$
}

\author{
Sergei A. Nizhnikov \\ Peoples' Friendship University of Russia, Moscow, Russian Federation \\ Le Thi Hong Phuong \\ Peoples' Friendship University of Russia, Moscow, Russian Federation
}

\begin{abstract}
One of the most important concepts of Buddhism is the idea of liberation, on the basis of which Buddhist ethical thought was built. Vietnamese monks defined the concept of liberation in their works and strove to put it into practice during a long historical time. Along with taking the "Noble Eightfold Path" of Mahayana Buddhism as the basis, the unique feature of the idea of liberation of Vietnamese Buddhism is that it is simultaneously influenced by both Chinese Buddhism and the ideas of Confucianism and Taoism. The authors analyze the concept of liberation in Vietnamese Buddhism by three main ideas: liberation as a revelation of the Buddha in self-awareness; liberation as self-reflection; release, requiring a positive incarnation in life.

Peculiarity of the liberation concept in Vietnamese Buddhism is the spirit of "unconcern" (absence of the fear before samsara), unconditional (independence from writings, dogmas, words), embodiments (harmony with life, making people free from sufferings caused by war and acts of nature), "turn inside" (looking into the heart in searches of liberation) and "a direction outside" (liberation of the people, the country).

The Vietnamese Zen-Buddhism asserts, that the way of liberation is an experience of acceptance by each person of absolute truth in the consciousness. The purpose of liberation is the nirvana surpassing all dualistic contradictions. Liberation is the returning to Buddha in the heart. Paying attention to a social origin of suffering, heart of the monk really released only then when people and the country do not suffer any more, do not live in misery.

The unique features of the Vietnamese Buddhism in many respects define by synthesizing of three religions values: an idea on renunciation - from Taoism, spiritual practice - from Mahayana Buddhism and spirit of an embodiment through sociopolitical activity - from Confucianism. Whereupon Mahayana Zen-Buddhism keeps the forming role.
\end{abstract}

Key words: liberation, enlightenment, Buddhism in Vietnam, Zen Buddhism, self-consciousness, Buddhist monasticism.

\section{ОСОБЕННОСТИ КОНЦЕПЦИИ ОСВОБОЖДЕНИЯ ВО ВЬЕТНАМСКОМ БУДДИЗМЕ ${ }^{1}$}

\author{
Сергей Анатольевич Нижников \\ Российский университет дружбы народов, г. Москва, Российская Федерация \\ Ле Тхи Хонг Фыонг \\ Российский университет дружбы народов, г. Москва, Российская Федерация
}

Аннотация. Одним из важнейших понятий буддизма является идея освобождения, на основе которой строилась буддийская этическая мысль. Концепцию освобождения вьетнамские монахи определяют в своих 
произведениях и стремятся реализовать на практике в течение длительного исторического времени. Наравне с «Благородным восьмеричным путем» буддизма Махаяны, взятым в качестве основы, уникальной особенностью концепции освобождения во вьетнамском буддизме является то, что на нее одновременно влияют китайский буддизм, идеи конфуцианства и даосизма. В данной статье эта концепция анализируется во вьетнамском буддизме сквозь три основные идеи: освобождение как откровение Будды в самосознании; освобождение как саморефлексия; освобождение, требующее позитивного воплощения в жизни.

Особенность концепции освобождения вьетнамского буддизма - дух «безразличия» (отсутствие страха перед сансарой), безусловности (независимость от писаний, догм, слов), воплощзения (гармония с жизнью, освобождение народа от страданий, вызванных войной и стихийными бедствиями), «поворот внутрь» (обращенность к сердцу в поисках освобождения) и «направление вовне» (освобождение народа, страны).

Вьетнамский дзен-буддизм утверждает, что путь освобождения - это опыт принятия каждым человеком абсолютной истины в своем самосознании. Целью освобождения является нирвана, превосходящая все дуалистические противоречия. Освобождение - это возвращение к Будде в своем сердце. Обращая внимание на социальное происхождение страдания, сердце монаха по-настоящему освобождается только тогда, когда народ и страна больше не страдают, не бедствуют.

Уникальные особенности вьетнамского буддизма во многом определяются синтезированием ценности трех религий: мысль об отречении - из даосизма, духовная практика - из буддизма Махаяны, дух воплощения через социально-политическую деятельность - из конфуцианства. При этом за дзен-буддизмом Махаяны сохраняется образующая роль.

Ключевые слова: освобождение, просветление, буддизм во Вьетнаме, дзен-буддизм, самосознание, буддийское монашество.

В отличие от онтологии буддизма, изучающей проблему источника таковости, нирваны, концепция освобождения рассматривает проблему методик, практики и медитации. С точки зрения буддистской доктрины освобождение - это отказ от всех уз и страданий в поисках выхода из бедствий трилоки и достижения умиротворения и просветления. Другими словами, этот путь понимается как отказ от невежества, ошибок светского мира в целях достижения вечности.

По мнению О.О. Розенберга, буддийская этическая мысль строится на основе идеи «освобождения» [Rozenberg 1990, 189]. Понятие освобождения связано с человеком как субъектом, с его индивидуальным «Я». Человек является как источником для практики просветления, так и целью освобождения одновременно. При этом ему необходимо достичь состояния таковости, или переживания природы Будды, которое служит выходом из бесконечного круга реинкарнаций для достижения состояния вечности. В соответствии с философией буддизма это состояние есть в каждом человеке и достижимо с помощью методик самосовершенствования. Другими словами, только преодолев невежество и страдания, человек достигает освобождения [Nguyễn Công Lý 2002, 17]. Проблема освобождения связана также и с ответами на метафизические вопросы.
Для того чтобы избавиться от тревог и страданий, вьетнамские монахи воспитывают дух «мало желаний, достаточно знаний». Согласно учению Винитаручи (?-594), буддийского миссионера во Вьетнаме, выходца из Южной Индии, первая часть пути к просветлению - это избавление от желаний. Почтенный монах Чи Тхиен (1882-1943) 2 советовал придворным императора «гнать желания за тысячи миль, отпустить скрытые в них миражи» [Thiền uyển tập anh... 1990, 225]. Он также наставлял учеников практиковать нравственность в скромном образе жизни, сохранять благочестие. Почтенный монах И Шон (?-1243) ${ }^{3}$ считал славу и богатство эфемерными, подобными пузырю, поэтому всю жизнь лелеял мечту «сажать благословения, сеять возможности». Это смешение даосской философии жизни (дай место другому, но не теряй своего) и философии жизни буддизма (не завидуй, не воруй, не прелюбодействуй). Однако принцип «мало желаний, достаточно знаний» состоит в том, чтобы устранить желания, а желание вызвано невежеством. Поэтому для достижения освобождения необходимо искоренить первопричину страдания - невежество. Этот аспект привлекает внимание буддизма во Вьетнаме и находит в нем свою трактовку.

Дзен-буддизм - это течение буддизма Махаяны, согласно легенде, пришедшее из 
Индии и получившее большое распространение в Китае. Дзен-буддизм зародился в V-VI в., когда Бодхидхарма принес его в Китай, где оно вобрало в себя идеи даосизма. В Восточной Азии течение стало большой ветвью буддизма. Оно ставит целью осознание странствующим монахом сущности вещей и достижение нирваны, подобно тому как Будда Шакьямуни достиг нирваны у корней дерева Бодхи. В широком смысле дзэн - это школа мистического созерцания [Сафронова 1989,148$]$ или учение о просветлении, появившееся на основе буддийского мистицизма [Дюмулен 2003, 58]; в более узком - практика дзэнских школ, также обозначаемая понятием «дхьяна» [Степанянц (ред.) 2011, 283]. Во Вьетнаме он стал доминирующей формой буддизма.

Дзен-буддизм обращает внимание на опыт просветления, активно борется со всеми религиозными ритуалами и теориями о дхарме. Он рекомендует странствующим монахам медитировать, чтобы достичь просветления, что считается кратчайшим, а также самым сложным путем к нирване. Характеристики дзен-буддизма можно резюмировать следующим образом:

- Цзяо Вай Бе Чуань (教 外 別 傳) - особая передача вне священных писаний;

- Бу Ли Вэнь Цзы (不立文字) - отказ от опиры на слова и тексты;

- Чжи Чжи Жэнь Синь (直指 人心) - непосредственная связь с сознанием человека;

- Цзянь Син Чэн Фу (見性成佛) - созерцание своей природы, как Будды [Судзуки, Кацуки 1993, 35].

«Ланкаватара сутра» («Сутра явления [Благого Закона] на Ланке») - это никая (на пали - «объем», «текст», «собрание»), ставшая предпосылкой для рождения китайского дзен-буддизма, в ней в основном идет речь об опыте переживания абсолютной истины в сердце. Согласно никае путь освобождения - это очищение своего сердца. Дзенбуддизм также придает большое значение озарению или «мгновенному просветлению».

Под влиянием китайского дзен-буддизма буддизм во Вьетнаме выражает свой уникальный характер в концепции освобождения через три основные идеи: 1. Освобождение, или просветление, означает нахождение Буд- ды в сердце. 2. Освобождение означает внутреннюю осознанность, пробуждающую природу Будды в сердце без необходимости посредничества языка и знания. 3. После нахождения Будды в своем сердце освобождение состоит в том, чтобы жить жизнью простоты, невинности, правды, гармонии с природой, обычной жизнью (дух воплощения).

\section{1. Освобождение как поиск Будды в самосознании}

Идея «Будды в самосознании» или «Будды в сердце» исходит из концепции единства между конечным и бесконечным, относительным (мир феноменов) и абсолютным (сущность, таковость, природа Будды). Бесконечное скрыто в конечном, абсолютное - в относительном, так и солнце, и луна заключены в маленьком горчичном зернышке, весь необъятный мир бесконечен в перышке [Thiền uyển tập anh... 1990, 218]. Это абсолютное называется многими именами: в дзен-буддизме Вьетнама - «переправа», «воплощение Будды», «пустота», «у-вэй» («недеяние»), а в каждом человеке - «таковость», «природа Будды», «печать просветления».

Вьетнамские монахи верят, что каждый человек рождается с сердцем свободным, ясным, первозданным, чистым и полным, без изъянов, - с сердцем Будды. По словам Винитаручи, эта сущность превосходит все дуалистические противоречия и не может быть выражена словами. Чанг Тхай Тонг (1218 1277 гг.) ${ }^{4}$ именует сердце «древним лицом», другими словами, это «изначальное сердце» («суть сердца»), в то время как Туэ Чунг Тхыонг Ши (1230-1291 гг. ${ }^{5}$ называет его «лицом матери», «родиной» или «источником». Но изза вращения в кругах сансары и перевоплощения погребенные под собственными желаниями люди не осознают в себе наличия этого «источника» и не возвращаются к своей природе Будды. Это трагедия человеческой жизни, от которой все должны быть освобождены.

Почтенный монах Чан Кхонг (1045$1100)^{6}$ считал, что просветление - это достижение у-вэй (недеяние), означающее возвращение домой, как обращение к своему сердцу, чтобы увидеть в нем сокрытую природу 
Будды. Великий учитель Хыонг Вьет (9331011) ${ }^{7}$ сказал, что природа Будды есть в людях, также как огонь в дереве, только нужно просветление, чтобы вспыхнул свет. Когда почтенный монах Тхиен Хой (?-900 гг.) ${ }^{8}$ спросил почтенного монаха Кэм Тханя (?-860 гг. $)^{9}$, что есть природа Будды, тот рассказал такую историю: «Кто-то однажды спросил Мацу Дайой: "Сердце - это Будда, Будда - это сердце, так что же такое Будда?" Мацу Дайой переспросил: "Если сомневаешься, что чтото не есть Будда, то как это показать?", человек не смог ответить. Мацу Дайой ответил: "Глубокое понимание - это осознание, что Будда во всем. Не достигнув просветления, ты вечно будешь неправ"» [Thiền uyển tập anh... 1990, 38]. Почтенный монах считал, что природа Будды повсюду, она проявляется прямо в жизни, но только мудрые люди могу понять это. Монахиня Зиеу Нян (1041-1113 гг.) ${ }^{10}$ сказала человеку, который пришел учиться буддизму Махаяны: «Если вернешься к источнику самопознания, то достигнешь просветления, все зависит от человека» [Thiền uyến tập anh... 1990, 234]. «Источник самопознания» - это просвещенное царство Бодхи, которое находится прямо в светском мире, внутри каждого человека, поэтому нет необходимости искать далеко, нужно только повернуться к Будде в своем сердце.

Император и почтенный монах Чан Тхай Тонг считал, что освобождение - это возвращение к первоначальному лику каждого человека - природе Будды, покрытой тенью невежества, похоти. Возвращение к «древнему лицу» означает, что заблудившийся ребенок вернулся домой, на древнюю родину, спасаясь от тьмы человеческой жизни, чтобы жить свободной умиротворенной жизнью, стать «живым Буддой» в середине пыльной жизни: «сердце миллионов - это сердце Будды». Дух великого учителя Трук Лама советовал императору Чан Тхай Тонгу, когда тот намеревался отправиться монахом в горы: «В горах нет Будды, Будда находится в сердце. Сердце тихо, но понятно; именно это и есть Будда. Если император познает это, то немедленно станет Буддой, и не нужно будет страдать от внешних поисков» [Trần Lê Sáng 1994, 40].

Туэ Чунг Тхыонг Ши также искал пустоту абсолютного бытия через разрыв с дуа- лизмом. По его словам, люди, не понимая, разделяют право и лево, тьму и свет, полноту и пустоту, истину и ложь, Будду и смертных. Таким образом, дуализм является продуктом затуманенного ума, а не правилом объективного мира. Зачарованный ум породил дуализм, который мучает людей, заставляет страдать. Следовательно, просветление, освобождение должны быть направлены внутрь, чтобы устранить суть дуализма, возвратиться к «пустоте», которую он называет «лицом матери» или «источником». После осознания пустоты больше нет различия. Все определяется как сердце, но в конечном счете сердца тоже нет. Жизнь - это большой сон, в этом большом сне «рождается большое и маленькое», но после пробуждения (просветления) нить пряжи не отличается от волоса.

Основываясь на концепции «Будда в сердце», Чан Нян Тонг (1258-1308 гг.) ${ }^{11}$ также искал истину в сердце. Просветленное сердце превосходит дуальность мира: оно - «сущность природы, без изъяна, не доброе, не злое» [Nguyễn Tài Đông 2008]. В стихе «Счастье peальной жизни» монах проанализировал путь, чтобы достичь света сердца. Молясь об освобождении, люди часто ищут сильного Будду вовне. Но на самом деле Будда находится в «доме», иначе говоря, в пяти скандках, в сердце каждого человека: «Будда находится в доме / Не нужно смотреть далеко / Человек должен найти Будду / Черный Будда - это я» [Степанянц (ред.) 2011, 506]. Из-за того, что оно покрыто пылью люди не осознают сияние сердца, но на самом деле чистое сердце - это будда кшетра (Миры Будды), Амитаба (Amitābha, безграничный свет), Сукхавати (Обитель блаженства; Чистая Земля будды Амитабхи в буддизме Махаяны). Чан Нян Тонг пишет: «Рядом три тысячи ученых трудов, доступны многочисленные эффективные методы. Если есть дисциплина, душевное спокойствие и мудрость, тогда нужно просто заглянуть в сердце» [Trần Lê Sáng 1994, 506].

Таким образом, вьетнамский дзен-буддизм утверждает, что путь освобождения это опыт принятия каждым человеком абсолютной истины в своем самосознании. Его целью является нирвана, превосходящая все дуалистические противоречия. Освобождение - это возвращение к дому природы Буд- 
ды в своем сердце, избавление от невежества, скорби, воскрешение природы Будды в глубине сознания каждого человека.

\section{2. Освобождение как саморефлексия без посредников}

Дух освобождения без посредников в дзен-буддизме Вьетнама - это невербальный, безусловный дух, находящийся под влиянием духа «отказа от догм» китайского дзен. Для дзен просветление не является знанием в четких и ясных рассуждениях. Оно представляет собой знание интуиции, высвобождение духовной силы человека, превосходящей язык. Язык конечен и не описывает абсолютную истину. Жизнь лежит в потоке времени без повторений. Медитация захватывает «текущее настоящее» в каждый момент жизни. Язык и философия отражают прошедшее. Нельзя использовать прошедшее для описания настоящего, дзен не прибегает к языкам. Во вьетнамском дзен-буддизме считается, что освобождение - это жить «настоящим», выходящим за рамки языка и сложной философии.

Дзен избегает пути догматического мышления, открывая другой путь, чтобы войти в сущность вещей, - «понимание без слов». Будда только молча протянул ветку с цветком, в ответ на метафизические вопросы. Махакашьяпа молча улыбнулся. Будда передал печать просветления Махакашьяпе. Это и есть дзен. Он использует интуицию, чтобы непосредственно войти в сущность всех вещей, чтобы увидеть связи между противоречиями и различиями. Из-за этого дзен экономно использует язык. В некоторых случаях его необходимо использовать, но в конце концов от языка нужно отказаться, освободить и отпустить сердце. По этой причине почтенные монахи течения дзен мало пишут. Работы по дзен-буддизму до сих пор в основном представляют собой просто строфы, которые мастера дзен произносят перед уходом в другой мир, когда сердце «возгорается от абсолютного просветления», достигает высшего состояния сердца Будды. Течение дзен-буддизма «Во Нгон Тхонг» (без языка) довольно четко выражает принцип отказа от использования языка: не используйте громоздкий язык для распространения учения, а используйте язык сердца. В этом духе почтенный монах Кам Тхань назвал себя «безъязыким», почтенный монах Тхиен Хой назвал ловких лжецов людьми, которые делают бесполезные вещи, но не могут проколоть панцирь черепахи и сломать черепицу. Для большинства мастеров дзен концепция освобождения означает независимость, безусловность, они не связаны ни с чем, включая буддийские учения и писания.

Буддизм в периоды династий Ли (10901225 гг.) и Чан (1225-1400 гг.) $)^{12}$ яростно критиковал монахов-догматиков, схоластиков, которые знали только чтение молитв Будде для сохранения мира. Это «потерянные тысячи миль». Монахиня Зиеу Нян считала, что чтение буддийских молитв - «прелесть», введение в заблуждение. Туэ Чунг Тхыонг Ши полагал, что, когда люди видят природу Будды в своем сердце, достигают цели освобождения, тогда необходимо освободиться от учения, потому что оно только подобно буйволу, который растворится в бесконечности освобождения [Trần Lê Sáng 1994, 249]. В стихе «Счастье реальной жизни» Чан Нян Тонг утверждает: «Когда я нахожу свет в моем сердце, нет необходимости искать Будду, нет необходимости различать северное и южное учение о дзене» [Trần Lê Sáng 1994, 504]. Отказ от языка - это яркая особенность дзен, делающая вьетнамский дзен времени династии Ли-Чан явлением совершенно уникальным и особенным. Данное течение буддизма выражает абсолютную веру в человека, который подчинил себе обстоятельства и овладел своим сердцем.

\section{3. Реализация освобождения в жизни}

Исследуя мысли буддизма, можно увидеть Будду сторонником реализма. Освобождение или нирвана, если она бесполезна для реальной жизни, сама по себе ничего не значит. Она может быть испытана прямо сейчас, то есть всякий раз, когда люди разрывают все узы алчности и вожделения, душа освобождается и человек достигает истинного освобождения. Это уникальный аспект буддийской мысли по сравнению с другими учениями, которые отрицают освобождение в реальном мире и считают, что только когда 
люди соединяют свое «Я» с величием вселенной, происходит освобождение.

Отметим следующие черты концепции освобождения во вьетнамском буддизме.

- Освобождение - это жизнь в гармонии со вселенной, природой.

Во вьетнамском буддизме нахождение Будды в сердце - только часть пути дзен к освобождению. Вьетнамские почтенные монахи не разделяют полностью сердце и жизнь, абсолютное и относительное. Бесконечное существует в конечном, заимствуя конечное, чтобы выразить себя. Поиск бесконечного за пределами конечного - это сокращение пространства и времени, самоуничтожение. Для того чтобы преодолеть это противоречие в буддизме Махаяны вьетнамский дзен искал освобождение от перерождений сансары. Этот дух происходит из корня концепции буддизма Махаяны («только в сансаре освободишься от круга сансары») в сочетании с влиянием южного течения дзен Хуэйнэн (638-713, Китай) ${ }^{13}$ и духом у-вэй даосизма.

В течении дзен «У Яньтун» или «Во Нгон Тхонг» почтенный монах Вьен Тьеу (9991090) ${ }^{14}$ четко выразил философию истинной, свободной жизни. Путь освобождения путем мучительных практик, излишних усилий был заменен естественной и комфортной жизнью: «Хочешь - возьми трость и погуляй по горной дороге, устанешь - опусти полог и ложись на бамбуковую кровать» [Thiền uyển tập anh 1990, 74]. В конце концов люди не могут выйти за пределы жизни, чтобы где-то далеко в абстракции найти мост бесконечности. Тем не менее все, даже почтенные монахи, должны есть и одеваться.

Туэ Чунг Тхыонг Ши, которого называют «яркой звездой в саду дзена Вьетнама», создал уникальную концепцию освобождения с духом отказа от догм. В рамках отказа от дуализма он не отделяет Дао от жизни, но считает, что Дао есть в жизни, в жизни есть Дао и Будда. Будда в жизни подобен ароматному лотосу, растущему в мутной воде. Поэтому нужно найти Дао, Будду в жизни. Ocвобождение для него абсолютно не имело следов отдаления от жизни и аскетической практики. Напротив, он считал, что просветленный человек должен быть погружен в жизнь, следовать закону Неба, закону Дао, то есть «жить повседневной жизнью, принимать свет и грязь, жить по правилам природы» [Trần Lê Sáng 1994, 397]. В отличие от большинства монахов, он отрицал буддийские ритуалы, освобождение у него означает возвращение к жизни с собственным «истинным лицом». Это жизнь, которая не связана правилами, догмой, пустотой. Люди живут по-настоящему с тем, что имеют, со своими искренними желаниями, свободно, здесь и сейчас.

В стихотворении «Радость реальной жизни» (Чан Нян Тонг) концепция освобождения испытывает сильное влияние даосизма: «На земле радость бытия доступна, если голоден - ешь, если устал - спи, дома есть сокровище, когда видишь трудности и страдания, то не спрашивай для чего медитация» [Trần Lê Sáng 1994, 510]. Это гибкий дух человека, который знает, как себя вести при всех обстоятельствах, изменениях в жизни, следует судьбе, но деятелен, работает, если должен, при любых обстоятельствах ведет себя в соответствии с ними. Драгоценная жемчужина - это природа Будды, которая уже в моем сердце, она неизменна, может помочь посреди бесприютной, безбрежной жизни. В этот момент уже нет необходимости спрашивать Будду, потому что я уже Будда.

У Чан Минь Тонга в старости была мудрая жизнь освобождения в «здесь и сейчас»: «Когда ты голоден, у тебя есть чаша с рисом, вода в полном кувшине утолит жажду, на подушке на кровати можно вздремнуть днем, это истинное счастье, "не нужно смотреть в книги, Будда о них не думает”, поэтому “внешний поиск очень мучителен, всем нужно дышать, раньше или сейчас - ничего не меняется"» [Thơ văn Lý - Trần 1977, 813]. Для почтенного монаха Хюен Куанга освобождение - это забвение себя, всех вещей, времени. Люди, которые практикуют духовную жизнь, также заняты работой обычных людей, они не повторяют сутры. Но есть и те, кто воплощает себя в жизни, сливается с ней.

Освобождение во вьетнамском дзен-буддизме также означает подъем на высоту вселенной, нахождение гармонии с природой, достижение минут полноты жизни, когда больше нет различия между людьми и миром вокруг, собой и окружающим. Люди осмелились 
«подняться до уровня Будды, подняться на вершину всего» (Туэ Чунг Тхыонг Ши). Например, когда почтенный монах Кхонг Ло поднялся на вершину горы, «издал звук, который заморозил небо». Этот титан избежал всех ограничений священных книг, жизни, достиг вершины слияния с пределом существования, чтобы воплотиться в безграничной вселенной.

Если вы голодны - ешьте, испытываете жажду - пейте, вам не нужно молиться Будде. Когда все станут Буддами, никому не нужно будет идти в монастырь, некому будет передавать буддийские книги. Однако это понимание предназначено для просветленных, таких как Чан Нян Тонг и Туэ Чунг Тхыонг Ши «живых Будд», которые достигли просветления в своих сердцах. Горы - всего лишь горы, реки - всего лишь реки, но взгляд непросветленного человека отличается от взгляда просветленного. Поэтому, согласно Туэ Чунг Тхыонг Ши и Чан Нян Тонгу, те, кто еще не достиг просветления, все еще должны молиться Будде и следовать правилу воздержания по такому принципу: для того, чтобы переплыть реку, нужен плот, который после достижения берега можно бросить.

Дух освобождения во вьетнамском буддизме - это дух одновременно трех религий. Однако путь освобождения погружается в духовную глубину, поднимается на вселенскую высоту, но еще не имеет широты человеческого мира, поэтому освобождение не достигнуто. Без фактора воплощения в мир и реализации мы не можем говорить о вьетнамском буддизме, с его концепцией человеческого освобождения и альтруизма.

- Освобождение связано с истинным патриотизмом.

Истинный патриотизм - это особенность духа освобождения вьетнамского буддизма. Его воплощение означает не только жить в гармонии с миром, но и побуждать людей делать хорошие вещи в мирской жизни.

Обращая внимание на социальное происхождение страдания, на то, что Дао и есть жизнь, путь освобождения во вьетнамском буддизме направлен не только на развитие сердца человека, но и на активное участие в национально-освободительных движениях, народном строительстве, спасении жизни людей. Сердце монаха по-настоящему освобож- дается только тогда, когда народ и страна больше не страдают, не бедствуют. В этом смысле вьетнамский буддизм находится под влиянием конфуцианства.

Согласно концепции «понимание и сопереживание окружающим» Чан Нян Тонга, «все вещи - это сердце Будды (сердце всего сущего - это сердце Будды)». Туэ Чунг Тхыонг Ши показывает, что путь освобождения во вьетнамском буддизме заключается не в том, чтобы вырваться из реальности страны, а в том, чтобы присоединиться к ней и сделать добро для всей страны и нации. Поэтому вьетнамские почтенные монахи больше устремлены в жизнь, а не только знают недоступные горы и глубокие ущелья, чтобы монашествовать и искать личного освобождения. Они участвовали в делах императорского двора, желали принести пользу стране. При династиях Ли-Чан многие монахи были яркими примерами духа сострадательной радости. Прежде чем остричь волосы, монахиня Зьеу Нян раздала все золото и украшения людям. Монах Виен Хок «круглый год носил только один предмет одежды» [Thiền uyển tập anh... 1990, 78], помимо проповедования буддизма, он также заботился о жизни, - «строил мосты, ремонтировал дороги, не было работы, за которую он бы не взялся» [Thiền uyền tập anh... 1990, 78]. Монах Тинь Тхуен считал изучение закона дзен главным, «постоянно заботился о благосостоянии народа» [Thiền uyển tập anh... 1990, 78]. Почетный монах Виен Тхон (1080-1151 гг.) ${ }^{15}$ безмерно заботился о делах императорского двора, поэтому всегда советовал императору действовать по принципу «оберегать все живое», чтобы помочь народу, уменьшить его страдания [Thiền uyển tập anh... 1990, 78].

У Чан Нян Тонга дух воплощения проявился очень четко. Как король и монах он не мог полностью избежать ограничений своей жизни, чтобы освободиться. Это положение привело к развитию его буддийской философии воплощения и более глубокому пониманию патриотизма. Благодаря этому философия освобождения Чан Нян Тонга приобрела позитивный оттенок и стала вершиной вьетнамского буддизма. Будучи императором, он преуспел в своей политической роли как лидер двух войн сопротивления против армии монголов, защищал страну и при этом выступил в роли культуролога, когда создал собственную письмен- 
ность для вьетнамцев в период феодализма письмо тьы-ном. Чан Нян Тонг стал патриархом течения Чук Лам Иен Ты ${ }^{16}$ - собственной школы дзен вьетнамского народа. Когда в стране установился мир, он был готов отказаться от престола, чтобы стать монахом. То, что Чан Нян Тонг путешествовал по всей стране, чтобы распространять и рассказывать о добре, было проявлением стремления сделать буддизм главной идеологией для продвижения позитивных ценностей и содействовать строительству мирной благополучной страны со счастливым народом. Его жизнь действительно была похожа на жизнь Будды Шакьямуни.

Хотя концепция освобождения основана на буддизме Махаяны, она сформирована и развита во вьетнамской культуре благодаря мыслям выдающихся монахов. Особенностью данной концепции во вьетнамском буддизме является дух «безразличия» (отсутствие страха перед сансарой), безусловности (независимость от писаний, догм, слов), воплощения (гармония с жизнью, освобождение народа от страданий, вызванных войной и стихийными бедствиями), «поворот внутрь» (обращенность к сердцу в поисках освобождения) и «направление вовне» (освобождение народа, страны). В этом сплаве - уникальные особенности вьетнамского буддизма, во многом синтезировавшего ценности трех религий: мысль об отречении - из даосизма, духовная практика - из буддизма Махаяны, дух воплощения через социально-политическую деятельность - из конфуцианства. При этом за дзен-буддизмом Махаяны сохраняется образующая роль.

\section{ПРИМЕЧАНИЯ}

${ }^{1}$ Исследование осуществлено в рамках проекта РНФ № 19-18-00118 «Россия и буддийский мир в дискурсе философского востоковедения».

The study was carried out within no. 19-18-00118 "Russia and the Buddhist World in the Discourse of Philosophical Oriental Studies" project of the Russian Science Foundation.

${ }^{2}$ Почтенный монах Чи Тхиен (вьет. Sư Trí Thiền, 1882-1943) - буддийский монах, революционный активист Вьетнама.

${ }^{3}$ Почтенный монах И Шон (вьет. Thiền sư Son, ?-213) - 19-е поколение школы дзен-буддизма Винитаручи.
${ }^{4}$ Чанг Тхай Тонг (вьет. Trần Thái Tông, 1218 1277) - вьетнамский буддист, правитель династии Чан.

${ }^{5}$ Туэ Чунг Тхыонг Ши (вьет. Tuệ Trung Thuợng Sĩ, 1230-1291) - один из наиболее значимых деятелей буддизма в средневековом Вьетнаме, крупный наставник и поэт.

${ }^{6}$ Почтенный монах Чан Кхонг (вьет. Thiền Su Chân Không, 1045-1100) - 16-е поколение школы дзен-буддизма Винитаручи.

${ }^{7}$ Хыонг Вьет (вьет. Khuông Việt, 933-1011) монах школы Дзен-буддизма У Яньтун.

${ }^{8}$ Тхиен Хой (вьет. Thiện Hội, ?-900 гг.) - монах,18-е поколение школы Дзен-буддизма У Яньтун (кит. трад. 無言通, вьет. Vô Ngôn Thông, 759826 гг.), основатель одноименной вьетнамской буддийской традиции внутри школы Дзен-буддизма.

${ }^{9}$ Кэм Тхань (вьет. Cẩm Thành, ?-860) -2-е поколение школы дзен-буддизма Винитаручи.

10 Зиеу Нян (вьет. Diệu Nhân, 1041-1113) 17-е поколение школы дзен-буддизма Винитаручи.

${ }^{11}$ Чан Нян Тонг (вьет. Trần Nhân Tông, 12581308) - 3-й императором династии Чан.

12 Династия Чан (вьет. Nhà Trần, 1225-1400) одна из династий Вьетнама, носившего название «Дайвьет»; династия Ли (вьет. Nhà Lý, 1090-1225) одна из династий, правивших вьетнамским государством Дайковьет.

${ }^{13}$ Хуэйнэн (вьет. Huệ Năng, 638-713 гг., кит. трад. 慧能) - патриарх китайского Дзен-буддизма, одна из важнейших фигур в традиции. Он отстаивал «внезапный» подход к буддистской практике и просветлению, и в связи с этим считается основателем южной школы Дзен-буддизма, ставшей с течением времени господствующей.

${ }^{14}$ Вьен Тьеу (вьет. Viên Chiếu, 999-1090) - буддийский монах, лидер вьетнамского буддизма во времена династии Ли, один из 7 монахов 7-го поколения линии дзен-буддизма У Яньтун.

${ }^{15}$ Виен Тхон (вьет. Viên Thông, 1080-1151) почтенный монах, 18-е поколение школы дзен-буддизма Винитаручи.

${ }^{16}$ Чук Лам Иен Ты (вьет. Trúc Lâm Yên Tử) вьетнамская школа дзен-буддизма, образованная во времена династии Чан, основанной королем Чан Нхан Тонгом. Она представляет собой единство трех вьетнамских линий дзен XII в. - Тао Дуонг, У Яньтун и Винитаручи.

\section{СПИСОК ЛИТЕРАТУРЫ}

Дюмулен 2003 - Дюмулен Г. История дзэн-буддизма. М.: Центрполиграф, 2003.

Сафронова 1989 - Сафронова Е.С. Основные направления распространения дзэн-буд- 
дизма в странах Запада // Вопросы научного атеизма : Мистицизм: проблемы анализа и критики. М.: Мысль, 1989. № 38. C. $147-166$.

Степанянц (ред.) 2011 - Степаняни М.T. (ред.). Философия буддизма: энциклопедия. М.: Восточная литература, 2011.

Судзуки, Кацуки 1993 - Судзуки Д.Т., Каиуки С. Дзэн-Буддизм: Основы Дзэн-Буддизма. Практика Дзэн. Бишкек: Одиссей, 1993.

Nguyễn Công Lý 2002 - Nguyễn Công Lý. Mấy ý kiến nhỏ về vấn đề giải thoát luận và những con đường tu chúng trong vãn học Phật giáo thời Lý - Trần // Tạp chí nghiên cưu Phật học. 2002. № 6. Trang 17-21.

Nguyễn Tài Đông 2008 - Nguyễn Tài Đông. Việt Nam hóa Phật giáo ở Trần Nhân Tông // Tạp chí Triết học. 2008. Số 12 (211). Trang 38-46.

Rozenberg 1990 - Rozenberg O.O. Phật giáo - Nhũng vấn đề triết học. Hà Nội: Trung tâm tài liệu Phật học xuất bản, 1990.

Tho văn Lý-Trần 1977-Tho văn Lý - Trần. Viện Văn học. T. 2. Hà Nội: Nhà xuất bản Khoa học Xã hội, 1977.

Thiền uyển tập anh... 1990 - Thiền uyển tập anh. Phân viện nghiên cưu Phật học. Hà Nội: Nhà xuất bản Vãn học, 1990.

Trần Lê Sáng 1994 - Trần Lê Sáng. Tồng tập vãn học Việt Nam. Tập 2. Hà Nội: Nhà xuất bản Khoa học xã hội, 1994.

\section{REFERENCES}

Dumoulin G., 2003. History of Zen Buddhism. Moscow, CJSC Tsentrpoligraf.

SafronovaE.S., 1989. The Main directions of Zen Buddhism in the West. Questions of scientific atheism: Mysticism: problems of analysis and criticism. Moscow, Mysl' Publ., no. 38, pp. 147-166.

Stepanyants M.T. (ed.), 2011. The philosophy of Buddhism: encyclopedia. Moscow, Eastern literature Publ.

Suzuki D.T., Kazuki S., 1993.Zen Buddhism: The Basics Zen Buddhism. Zen practice. Bishkek, Odyssey Publ.

Nguyen Cong Li, 2002. On the issue of the liberation of the treatise in the Buddhist literature of the period of the Li - Chan dynasties. Buddhist studies, no. 6, pp. 17-21.

Nguyen Tai Dong, 2008. Vietnamization of Buddhism by Tran Nhan Tong. Philosophy, no. 12 (211), pp. 38-46.

Rosenberg O.O., 1990. Buddhism - philosophical problems. Hanoi: Center for Buddhist literature.

Tho văn Lý - Trần, 1977. Institute of literature. Literature dynasties Lee and Chan. Vol. 2. Hanoi, General.

A collection of outstanding figures of the Zen garden. Institute of Buddhist Studies, 1990. Hanoi, Literature Publ.

Tran Le Sang, 1994. Complete works of Vietnamese literature. Vol. 2. Hanoi, Social Sciences Publ.

\section{Information about the Authors}

Sergei A. Nizhnikov, Doctor of Sciences (Philosophy), Professor, Department of the History of Philosophy, Peoples' Friendship University of Russia, Miklukho-Maklaya St., 10/2, 117198 Moscow, Russian Federation, nizhnikovs@mail.ru, https://orcid.org/0000-0002-3456-2445

Le Thi Hong Phuong, Master Student, Department of the History of Philosophy, Peoples' Friendship University of Russia, Miklukho-Maklaya St., 10/2, 117198 Moscow, Russian Federation, lethihongphuong@mail.ru, https://orcid.org/0000-0001-6334-4132

\section{Информация об авторах}

Сергей Анатольевич Нижников, доктор философских наук, профессор кафедры истории философии, Российский университет дружбы народов, ул. Миклухо-Маклая, 10/2, 117198 г. Москва, Российская Федерация, nizhnikovs@mail.ru, https://orcid.org/0000-0002-3456-2445

Ле Тхи Хонг Фыонг, магистрант кафедры истории философии, Российский университет дружбы народов, ул. Миклухо-Маклая, 10/2, 117198 г. Москва, Российская Федерация, lethihongphuong@mail.ru, https://orcid.org/0000-0001-6334-4132 